\title{
Efficacy of Alternative Vaccination with Attenuated Sheep Pox and Inactivated Lumpy Skin Disease Vaccines against Lumpy Skin Disease
}

*Christine A. Mikhael; **Ibrahim, M.M; and ** Saad, M.A. *Pox Department, Veterinary serum and vaccines research institute, Abbassia, Cairo, Egypt. **Evaluation of large animal viral vaccine Department, Central Laboratory for Evaluation of Veterinary Biologics (CLEVB), Cairo, Abbassia, Egypt.

\section{Abstract}

In different countries and sometimes within a country, various live attenuated vaccine have existed from time to time for capripox with varying degrees of protective efficacy. An experiment applied on eight groups of susceptible calves, were individually inoculated intradermally (I/D) or subcutaneously (S/C); In order to pinpoint the optimum program of vaccination against lumpy skin disease in the tail fold with one of the alternative vaccination programs by using attenuated Lumpy skin disease (LSD) vaccine, attenuated Romanian sheep pox (RSP) vaccine and inactivated LSD vaccine (separate; simultaneous or successive); in an attempt to obtain a safe and protective vaccination regem for cattle against lumpy skin disease.

The humoral immunity was checked out by serum neutralization test (SNT) and enzyme linked immunosorbent assay (ELISA) for 6 months post inoculation, while the cell mediated immune response was performed by the hypersensitivity reaction at the inoculation site after I/D inoculation with $0.5 \mathrm{ml}$ of attenuated undiluted LSD vaccine and its results corroborate the humoral results.

The results of humoral and cellular immune response proved that successive vaccination of cattle with live attenuated RSP vaccine prior to the inactivated LSD vaccine create relative acquired immunity subsequent to the homologous live attenuated LSD vaccine and overcome the immunological effect of the other used vaccines.

Our results nominate the homologous attenuated LSD vaccine (GP1) and successive vaccination (GP4\&5) with attenuated RSP vaccine before inactivated LSD vaccine for absolute protection of cattle from LSD. It was concluded that the successive vaccination (with attenuated RSP vaccine before inactivated LSD vaccine) is considered more safe and avoid viral reversion and transmission of the virus by the blood feeding arthropods.

Keywords: LSD, SP, successive vaccination, capripox, inactivated, cattle. 


\section{Introduction:}

Capripox viruses (CaPVs) is a genus in the chordopoxvirus (ChPV) subfamily of the Poxviridae (Tulman et al., 2001); it is comprised of lumpy skin disease virus (LSDV), sheeppox virus (SPV) and goatpox virus (GPV); which are responsible for the most economically significant diseases of domestic ruminants in Africa and Asia (Fields et al., 1996). CaPV have specific geographic distributions and generally are host specific (Davies 1991, Carn 1993, and Coetzer et al., 1994). CaPVs are, however, immunologically indistinguishable from each other, able to induce heterologous crossprotection (Capstick, 1959; Davies, 1982\&1991 and Carn, 1993).

LSD have two clinical forms in cattle including subacute and acute; it is clinically characterized by extensive cutaneous lesions and other complications include hide scare, skin myiasis, sever emaciation and death (Coetzer et al., 1994; Davies, 1991 and Salib and Osman, 2011). The most common method of transmission of LSD between cattle is recorded by arthropod vectors (MacOwen 1959; Davies, 1991; Carn, 1993; Barnard et al., 1994; Carn and Kitching, 1995; Yeruham et al., 1995 and Omnia et al., 2014). The controls of LSD in enzootic areas are achieved by using attenuated LSDV strains and SPV vaccines (Davies, 1991; Barnard et al., 1994; Carn et al., 1994; Yeruham et al., 1994).
LSD was reported for the first time in Egypt in 1988, where it had dramatic economic impact by reduction of milk yield and loss of weight gain in cattle deaths (Ali et al., 1990). The outbreak were recorded in several governorates starting from Ismailia and extended to Aswan and the desert oasis by the summer of 1989. Reappearance of LSD outbreak was recorded 17 years post the first appearance in Egypt in 2006, and it was suggested to be introduced into Egypt by importation of infected cattle from the African Horn countries (ElKholy et al., 2008).

The incidence of LSD is high in low lying wet areas because the high density population of insect vectors such as the delta, oases and along the Nile and also during the summer months because the rapid rate of insects multiplication.

It was observed in the recent LSD outbreaks in the Middle East region the vaccination failure due to different causes (Brenner et al., 2009). The only effective way to control the spread of LSDV in endemic countries by vaccination which is considered the most cheaply and sustainable means of disease control (Kallesh et al. 2009).

Eeva (2014) reported that due to cross-protection within the Capripoxvirus genus, sheep pox virus vaccines have been widely used for cattle against lumpy skin disease virus. In the Middle East and the Horn of Africa; recently 
these vaccines have been associated with incomplete protection against LSD which has been reported in cattle vaccinated with live attenuated SP vaccines (Ali et al., 1990; Khalafalla et al. 1993; Tamam, 2006; Marshall, 2006 Omyma, 2006; Brenner et al., 2009; $\quad$ Somasundaram, 2011;Tuppurainen and Oura, 2011 and Ayelet et al., 2013).

Hu SL et a1. (1991), reported that combined immunization including two types of vaccines may be more effective than either immunogen alone.

However, Tuppurainen et al. (2015), reported that the significant emergence of $\mathrm{CaPV}$ infection in the Middle and Near East; they illustrated that different problems were associated with the use of different CaPV vaccines.

All of the previous problems associated with using live attenuated Capripox virus vaccines represent pressing need for improving the control strategies against LSD in Egypt. So this paper describes the evaluation of a comparative programs of vaccination with different locally prepared vaccines used to control lumpy skin diseases in Egypt.

\section{Material and methods:-}

\section{Viruses:}

a- Romanian sheep pox virus (RSPV):

It was supplied from pox department, Veterinary Serum and Vaccine Research Institute
(VSVRI), Egypt. The virus was cultivated and propagated on African green monkey kidney cells (Vero cells) according to Singh and Rai (1991) and Rizkallah (1994).

b- Lumpy skin disease virus (LSDV):

It was supplied from pox department, VSVRI, Egypt. Ismailia strain (local isolate) was isolated from Egypt during the outbreak of 1988 (House et al., 1990). The virus was adapted in Madin-Darby bovine kidney cells (MDBK) according to Aboul Soud (1995) and Daoud et al. (1998).

2. Cell cultures:

a- African green monkey kidney cells (VERO):

The cells were used for propagation, preparation, titration of sheep pox vaccine and for serological test.

b- Madin-Darby bovine kidney cells (MDBK):

The cells were used for propagation, preparation, titration of LSD vaccine and for serological test.

The cell culture passaging and maintenance was carried out using Minimum Essential Medium (MEM) supplemented with newborn calf serum in addition to 100IU penicillin, $100 \mu \mathrm{g}$ streptomycin sulfate and 5IU Nystatin/ml, according to $\boldsymbol{U S E P A}$, Manual of Methods for virology, (1984).

3- Stabilizer:

The stabilizer used for preparation of live attenuated SP and LSD 
vaccines was the LactalbuminSucrose, in which the lactalbumin hydrolysate $(5 \%)$ was added to sucrose $(2.5 \%)$ in double distilled water (OIE 2010), the mixture was sterilized by filtration.

\section{4- Adjuvant:}

Montanide ISA 206 VG, produced by SEPPIC; make as recommended by the manufacture and used for preparation of inactivated LSD vaccine.

5- Conjugate: The Anti-bovine conjugate was used in ELISA.

6- Preparation of attenuated sheep pox and lumpy skin disease vaccines:

According to Vegad and Sharma (1973); Rizkallah (1994); and OIE (2010) propagation of the RSP virus seed on VERO cell culture, and according to Aboul Soud (1995) and Daoud et al. (1998) and OIE (2010) propagation of the local Ismailia strain seed LSD on MDBK cell culture, and harvested when the CPE reached to about $90 \%$.

The two different attenuated Romanian sheep pox and Ismailia lumpy skin disease vaccines were prepared by mixing of stabilizer solution with the virus fluid of attenuated virus at the ratio $1: 1$ (v:v). were badded to each $100 \mathrm{ml}$ vaccine $100 \mathrm{IU} / \mathrm{ml}$ penicillin, $100 \mu \mathrm{g} / \mathrm{ml}$ streptomycin sulfate and $5 \mathrm{IU} / \mathrm{ml}$ Nystatin then submitted to lyophilization and stored at $-20^{\circ} \mathrm{C}$.

7- Preparation of inactivated lumpy skin disease vaccines:

It was applied according to the method described by Capstic and
Coakley (1962); Saber et al. (2000) and Amal (2003).

8- Titration of caprine pox vaccines:

It was applied according to Rao and Malik (1982) and Tiwari and Negi (1995). The titre of any of the two virus vaccines was expressed by TCID $_{50}$ and calculated according to the method of Read and Muench (1938).

9- Sterility test:

Was carried out according to $\boldsymbol{O I E}$ (2010).

\section{0- Animals and vaccination:}

A number of 26 susceptible mixed breed calves 6-12 months old were used. They had no history of previous capripox vaccination and screened for freedom of specific antibodies against LSD virus. They were housed in an insect proof pens and were allocated into 8 groups each of three animals and 2 animals were left unvaccinated as isolated control group ( $9^{\text {th }}$ group), the calves were fed a complete balanced diet and water adlabium.

In each group two animals received $1 \mathrm{ml}$ of the field dose $\left(10^{2.5} \mathrm{TCID}_{50}\right)$ of each attenuated vaccine by I/D rout in the tail fold or $2 \mathrm{ml}$ of inactivated vaccine by $\mathrm{S} / \mathrm{C}$ rout with single, simultaneous or successive vaccination and the $3^{\text {rd }}$ one left unvaccinated as a contact control.

Vaccination was given as follows for the different group:

1.Vaccination with attenuated lumpy skin disease (LSD) vaccine. 
2. Vaccination with attenuated Romanian sheep pox (RSP) vaccine.

3. Vaccination with inactivated LSD vaccine.

4. Successive vaccination with attenuated RSP vaccine 4 weeks before inactivated LSD vaccine.

5. Successive vaccination with attenuated RSP vaccine 12 weeks before inactivated LSD vaccine.

6. Successive vaccination with inactivated LSD vaccine 4 weeks before attenuated RSP vaccine.

7. Successive vaccination with inactivated LSD vaccine 12 weeks before attenuated RSP vaccine.

8. Simultaneously vaccination with the two vaccines (attenuated RSP vaccine and inactivated LSD).

9. control two isolated non vaccinated animals.

Different injection sites and needles and syringes were used for concomitant parenteral injections.

The inoculated animals were observed daily for one month for recording post vaccinal reactions (including body temperature and swelling at the site of inoculation or generalized skin lesions).

\section{1- Serum samples:}

Were collected weekly from all the animals, samples were stored at $20^{\circ} \mathrm{c}$ until examined by the serological tests.

12- Evaluation of humeral immune response:

a. Serum neutralization test (SNT): It was carried out according to Martin et al. (1975; House et al. (1990a) and OIE(2010), and the neutralizing index (NI) was calculated according to Reed and Muench (1938).

b. Enzyme linked immunosorbent assay (ELISA):

It was done according to House et al. (1990); Sadhukan et al. (1998) and Babiuk et al. (2009).

13- Evaluation of the cell mediated immune response :

Sensitivity test: It was carried out according to Kitching et al. (1986) and Uppal et al. (1967). It was applied to avoid the injection with virulent LSD virus; in which the vaccinated and control animals were subjected to sensitization through I/D inoculation with $1 \mathrm{ml}$ of undiluted attenuated LSD vaccine in the dewlap on the end of the experiment (at end of $6^{\text {th }}$ months) and the inoculated animals were examined daily for three days for demonstration of hypersensitivity reaction at the inoculation sites.

\section{Results:}

\section{1-Preparation of attenuated sheep pox vaccines:}

The harvested virus fluid and the prepared vaccine batches were titrated on VERO cells and the average titre was recorded as illustrated in (Table 1).

\section{2-Preparation of attenuated} lumpy skin disease vaccine:

The harvested virus fluid and the prepared vaccine batches were titrated on MDBK cells and the average titre was recorded in (Table 2). 
3-Preparation of inactivated lumpy skin disease vaccines:

The titre of the used virus fluid was $10^{6.2} \mathrm{TCID}_{50} / \mathrm{ml}$.

\section{4-Result of sterility test:}

The result proved that the three types of capripox vaccines samples (attenuated SP \& attenuated and inactivated LSD) were free from any contaminants.

5-Post-vaccinal reactions of vaccination programs:

Different vaccinated groups showed in general slight increase in body temperature for 2-5 days post vaccination. The $1^{\text {st }}$ group vaccinated with attenuated LSD showed redness and hotness at the site of inoculation; on the $6^{\text {th }}$ day swelling of the inoculation area was occurred and its size was about 2-3 $\mathrm{cm}$ in diameter and started to diminish by the $15^{\text {th }}$ day with formation of firm scab, that indicating virus replication and it was disappeared within three weeks. On the other hand the animals inoculated with the inactivated LSD vaccine (group3,4,5,6,7\&8) showed variable enlarged local reaction $3-5 \mathrm{~cm}$ diameter and granulated at the inoculation site for 10-18 days due to the use of adjuvant. The $2^{\text {nd }}$ group (vaccinated with attenuated RSP vaccine) showed a very mild local reaction or undetectable swelling. The control contact or isolated control animals (group 9) showed no reaction and remained apparently clinically normal.
6-Evaluation of humeral immune response:

Serological assays (Serum Neutralization test (SNT) and ELISA):

They were applied on the blood sera of all cattle groups before and after vaccination; the result were present In table (3).

The different vaccinated groups are:

G1.Vaccination with attenuated lump skin disease (LSD) vaccine.

G2. Vaccination with attenuated Romanian sheep pox (RSP) vaccine.

G3. Vaccination with inactivated LSD vaccine.

G4. Successive vaccination with attenuated RSP vaccine 4 weeks before inactivated LSD vaccine.

G5. Successive vaccination with attenuated RSP vaccine 12 weeks before inactivated LSD vaccine.

G6. Successive vaccination with inactivated LSD vaccine 4 weeks before attenuated RSP vaccine.

G7. Successive vaccination with inactivated LSD vaccine 12 weeks before attenuated RSP vaccine.

G8. Simultaneously vaccination with the two vaccines (attenuated RSP vaccine and inactivated LSD).

7-Evaluation of cellular immune response (Sensitivity test):

The results proved that the $1^{\text {st }}$ group exhibited the highest cellular immunity, then the $4^{\text {th }}$ and $5^{\text {th }}$ group (successively vaccinated with attenuated RSP vaccine prior to inactivated LSD), then the $2^{\text {nd }}$ group which was vaccinated with the 
attenuated RSP vaccine and after that the 3groups $\left(6^{\text {th }}, 7^{\text {th }} \& 8^{\text {th }}\right.$ group) while the $3^{\text {rd }}$ group (vaccinated with the inactivated LSD alone) acquired the least cellular immunity.

The isolated and contact control non vaccinated animals showed no any obvious hypersensitivity reactions at the inoculation sites with the first 3 days post-inoculation.

The results proved that all prepared vaccines could be used in field without possibilities of transmission of the viruses to the contact non vaccinated animals.

Table (1): The average titre of the Romanian sheep pox virus fluid on Vero cells before and after lyophilization in $\log _{10} T C I D_{50} / \mathrm{ml}$ :

\begin{tabular}{|c|c|c|}
\hline $\begin{array}{c}\text { Batch } \\
\text { Number }\end{array}$ & Titre of RSP virus fluid & $\begin{array}{c}\text { Titre of lyophilized RSP } \\
\text { vaccine }\end{array}$ \\
\hline 1 & 5.6 & 5.0 \\
\hline 2 & 6.0 & 5.2 \\
\hline 3 & 5.8 & 5.1 \\
\hline
\end{tabular}

$\mathbf{T C I D}_{\mathbf{5 0}}=$ Tissue culture infective dose fifty.

The average titre of the virus fluid of three passages reached to $10^{5.8}$ $\mathrm{TCID}_{50} / \mathrm{ml}$ and after lyophilization $10^{5.1} \mathrm{TCID}_{50}$ (Table 1).

Table (2): The average titre of local Ismailia strain of LSD virus fluid on $M D B K$ cells before and after lyophilization in $\log _{10} T C I D_{50} / \mathrm{ml}$ :

\begin{tabular}{|c|c|c|}
\hline $\begin{array}{c}\text { Batch } \\
\text { Number }\end{array}$ & $\begin{array}{c}\text { Titre of LSD virus } \\
\text { fluid }\end{array}$ & $\begin{array}{c}\text { Titre of lyophilized LSD } \\
\text { vaccine }\end{array}$ \\
\hline 1 & 5.3 & 4.8 \\
\hline 2 & 5.4 & 4.9 \\
\hline 3 & 5.5 & 4.7 \\
\hline
\end{tabular}

$\mathbf{T C I D}_{\mathbf{5 0}}=$ Tissue culture infective dose fifty.

The average titre of the 3 batches fluid was $10^{5.4} \mathrm{TCID}_{50}$ and after lyophilization $10^{4.8} \mathrm{TCID}_{50} / \mathrm{ml}$. 
Table(3): Serological assays (SNT and ELISA) of the different groups:

\begin{tabular}{|c|c|c|c|c|c|c|c|c|c|c|c|c|c|c|c|c|}
\hline \multirow{2}{*}{ WPV } & \multicolumn{2}{|c|}{ G1 } & \multicolumn{2}{|c|}{ G2 } & \multicolumn{2}{|c|}{ G3 } & \multicolumn{2}{|c|}{ G4 } & \multicolumn{2}{|c|}{ G5 } & \multicolumn{2}{|c|}{ G6 } & \multicolumn{2}{|c|}{ G7 } & \multicolumn{2}{|c|}{ G8 } \\
\hline & NI & $\mathrm{S} / \mathbf{P}$ & NI & $\mathrm{S} / \mathbf{P}$ & NI & $\mathrm{S} / \mathbf{P}$ & NI & $\mathrm{S} / \mathrm{P}$ & NI & $\mathrm{S} / \mathbf{P}$ & NI & $\mathbf{S} / \mathbf{P}$ & NI & $\mathrm{S} / \mathbf{P}$ & NI & $\mathrm{S} / \mathbf{P}$ \\
\hline O & 0.50 & 0.40 & 0.50 & 0.3 & 0.5 & 0.4 & 0.5 & 0.4 & 0.5 & 0.5 & 0.5 & 0.2 & 0.5 & 0.4 & 0.5 & 0.4 \\
\hline 1 & 1.00 & 0.8 & 0.75 & 0.5 & 0.75 & 0.6 & 0.75 & 0.6 & 0.75 & 0.8 & 1.0 & 0.8 & 0.75 & 0.6 & 0.75 & 0.6 \\
\hline 2 & 1.50 & 1.2 & 1.25 & 0.9 & 1.00 & 0.8 & 1.50 & 1.0 & 1.25 & 1.0 & 1.0 & 0.8 & 1.25 & 0.8 & 1.0 & 0.8 \\
\hline 3 & 1.75 & 1.2 & 1.50 & 1.2 & 1.25 & 1.0 & 1.75 & 1.2 & 1.75 & 1.3 & 1.25 & 1.0 & 1.25 & 1.2 & 1.5 & 1.0 \\
\hline 4 & 2.00 & 1.6 & 1.75 & 1.2 & 1.25 & 1.0 & 1.75 & 1.4 & 2.00 & 1.5 & 1.5 & 1.0 & 1.5 & 1.2 & 1.5 & 1.1 \\
\hline 5 & 2.50 & 1.8 & 1.75 & 1.4 & 1.50 & 1.0 & 2.0 & 1.4 & 2.00 & 1.5 & 1.5 & 1.2 & 1.5 & 1.4 & 1.5 & 1.2 \\
\hline 6 & 2.75 & 1.8 & 2.00 & 1.4 & 1.5 & 1.1 & 2.5 & 1.6 & 2.00 & 1.4 & 1.75 & 1.0 & 1.75 & 1.5 & 1.75 & 1.2 \\
\hline 7 & 3.00 & 2.0 & 2.25 & 1.5 & 1.75 & 1.2 & 2.75 & 1.8 & 2.00 & 1.6 & 1.75 & 1.3 & 2.00 & 1.5 & 2.0 & 1.2 \\
\hline 8 & 3.50 & 2.2 & 2.50 & 1.6 & $2.00^{*}$ & 1.2 & 3.00 & 2.00 & 2.5 & 1.8 & 2.25 & 1.5 & 2.00 & 1.5 & 2.25 & 1.4 \\
\hline 10 & $3.75^{*}$ & 2.2 & $2.75^{*}$ & $2.1 * *$ & 2.00 & 1.2 & $3.25 *$ & $2.35 * *$ & 2.75 & 2.0 & 2.5 & $1.7^{* * *}$ & 2.00 & 1.3 & 2.25 & 1.6 \\
\hline 12 & 3.75 & $2.6 * *$ & 2.75 & 2.0 & 2.00 & 1.2 & 3.25 & 2.25 & 2.75 & 2.2 & $2.5^{*}$ & 1.5 & 1.75 & 1.2 & $2.5 *$ & $1.8^{* * *}$ \\
\hline 14 & 3.50 & 2.5 & 2.50 & 1.9 & 2.00 & $1.4 * *$ & 3.25 & 2.25 & 3.0 & 2.2 & 2.5 & 1.4 & 1.75 & 1.1 & 2.5 & 1.7 \\
\hline 16 & 3.50 & 2.5 & 2.50 & 2.0 & 1.75 & 1.4 & 3.25 & 2.25 & $3.50^{*}$ & 2.4 & 2.5 & 1.4 & 2.25 & 1.6 & 2.25 & 1.6 \\
\hline 18 & 3.50 & 2.2 & 2.50 & 1.8 & 1.75 & 1.3 & 3.25 & 2.25 & 3.50 & $2.7^{* * *}$ & 2.5 & 1.5 & 2.25 & $1.9^{* * *}$ & 2.25 & 1.7 \\
\hline 20 & 3.50 & 2.1 & 2.50 & 1.8 & 1.5 & 1.0 & 3.00 & 2.0 & 3.50 & 2.4 & 2.25 & 1.2 & $2.50^{*}$ & 1.8 & 2.25 & 1.6 \\
\hline 24 & 3.50 & 2.1 & 2.25 & 1.7 & 1.75 & 1.0 & 3.00 & 2.0 & 3.25 & 2.2 & 2.0 & 1.2 & 2.00 & 1.6 & 2.25 & 1.5 \\
\hline
\end{tabular}

WPV = Week post vaccination.

$\mathbf{G}=$ Group

$\mathbf{N I}=$

Neutralizing index.

$*=$ highest NI

Shadow $=$ time of $2^{\text {nd }}$ vaccination.

$\mathbf{S} / \mathbf{P}=$ Sample to positive ratio.

N.B.1: Neutralizing Index $(\mathrm{NI}) \geq 1.5$ considered protective (Cottral, 1978).

N.B.2: ELISA RESULT (S/P) > 1.0 considered protective Babiuk et al. (2009).

N.B.3: Isolate and contact control calves persist negative NI till (24 weeks post vaccination), i.e. NI not exceeded 0.75 and ELISA titre not exceeded 0.7 .

\section{Discussion}

The first appearance of lumpy skin disease (LSD) occurred in Egypt in May 1988, in Ismailia quarantine, and the disease was spread allover the Egypt inspite of taking all control and eradication measures (Ali etal.,1990).
Vaccination is the most effective antiviral interposition which mobilizes the host's immune system to prevent viral infections, and when applied properly can be remarkably effective (Flint $\boldsymbol{e t}$ al., 2000 and Eeva et al., 2014).

The sheep pox virus (SP) vaccine have cross-protection against LSD 
in cattle in the Middle East and the Horn of Africa, these vaccines have been associated with incomplete protection and adverse reactions in cattle post vaccination (Ali et al., 1990; Ayelet et al. 2013; Brenner et al. 2009; Eeva et al., 2014; Khalafalla et al., 1993; Omyma, 2008 Somasundaram, 2011 and Tamam, 2006).

Eeva et al. (2014) and Tulman et al. (2002) reported that "the Kenyan sheep and goat pox vaccine virus (KSGP) is not sheep pox virus but is actually LSD. The low level attenuation of this virus is likely to be not sufficient for safe use in cattle causing clinical disease in vaccinated animals". Ayelet (2013) found that "the Kenyan sheep pox vaccine strain used for the control of LSD did not confer expected protection, and urges the need for investigation of vaccine failure including vaccine matching and alternative vaccine development; for this reason we select the Romanian sheep pox vaccine virus in this study".

Breenner et al., 2009; Davies, 1991; Kitching, 1986 and Somasundaram, 2011; reported that "Attenuated LSD vaccine are used against LSD infection in Southern Africa, because sheep pox (SP) and goat pox (GP) do not occur in this region. Whereas, in Central and northern Africa and in the Middle East, where the distribution of SP, GP and LSD overlap, attenuated SP vaccine, such as Romanian, RM65 and
Kenyan sheep pox strains have been used against LSD".

The vaccination failure and restrictions on the application of live LSDV vaccine created the need for more safe and effective vaccines (Barnard et al., 1994; Carn, 1993; Davies, 1991 and Yeruham et al. 1994).

For these reasons we tried to reach a safe and potent capripox vaccines for optimum control of lumpy skin disease in Egypt without complications and to be immunogenic in the field. In Egypt and nearly all over the world no one tried to use more than one capripox vaccine against $L S D$, in which according to the available literatures, little or nothing is known about the successive capripox vaccines against LSD.

In this study three attenuated and inactivated Capripox vaccines were prepared and evaluated; it used for single, simultaneous or successive vaccination of cattle within eight groups beside a $9^{\text {th }}$ isolated non vaccinated group (control).

Table (1) indicated that; the average titre of the lyophilized sheep pox vaccine was $10^{5.1} \mathrm{TCID}_{50} / \mathrm{ml}$ and table (2) indicated the average titre of the lyophilized lumpy skin disease vaccine was $10^{4.6} \mathrm{TCID}_{50} / \mathrm{ml}$ and the titre of the LSD vaccine fluid which used in preparation of inactivated LSD vaccine was $10^{5.4}$ $\mathrm{TCID}_{50} / \mathrm{ml}$. this is agree with $\boldsymbol{O I E}$ (2010), the prepared capripox vaccine should have a minimum titre $\log { }_{10} 4.5 \mathrm{TCID}_{50} / \mathrm{ml}$ after 
freeze-drying equivalent to a filed dose of $\log _{10} 2.5$ TCID $_{50} / \mathrm{ml}$.

Estimation of antibody response was applied on the serum samples, and we selected a serum neutralization (SNT) and enzyme linked immunosorbent assay (ELISA) for the different programs of vaccination. SNT is used for evaluation of antibodies to capripox virus (Tuppurainen, 2004), ELISA proved to have great potentiality as a quantitative serological tool in the detection of antibodies against several viral infections (William, 1987).

The obtained results recorded in table (3) proved that antibodies appeared from the $2^{\text {nd }}$ week and increased to the maximum titre on the $8^{\text {th }}$ and $10^{\text {th }}$ week post vaccination. The same results reported by ELISA. These results agreed with those obtained by Agag et al. (1992), Aboul Soud (1995), and Amal et al. (2007).

The results obtained from neutralization test were in conformity with ELISA for different vaccine programs (table 3 ); indicated that the antibody titre before vaccination with any of the different programs showed lower titre (0.2-0.7) while after vaccination appeared variable increase from vaccination to the other. NI was $(3.75,2.75,2.00$, $3.25, \quad 3.5, \quad 2.5, \quad 2.5$ and 2.5 ) respectively for the different groups ,the ELISA results were $(2.6,2.1$, $1.4,2.35,2.7,1.7,1.9$ and 1.8) respectively but the increase of antibodies was faster in the successive vaccination when the interval increased from 4 week to 12 week which was in agreement with Mervat (1999) who used NI to know the level and duration of immunity acquired from inactivated LSD vaccine in vaccinated cattle and reported that oil inactivated LSD vaccine had a higher titre after 4 weeks post vaccination 2.3 (NI) and decreased until 1.5 (NI) after 4 month post vaccination.

Our results corresponded to $\boldsymbol{U S}$ General recommendation on immunization (2006) which reported that the increase of the intervals among doses of a multi dose not decrease the effectiveness of the vaccine and decrease of the intervals among doses of multi dose vaccine may reduce antibody response and protection.

Considering the seroconversion in vaccinated and control groups of cattle with different vaccination programs by both SN and ELISA (table 3), showed that the antibody response varies from group to the other and recorded the highest level within the $1^{\text {st }}$ group which vaccinated with homologous attenuated LSD vaccine (G1), then the two groups which were successively vaccinated with the attenuated SP vaccine prior to vaccination with inactivated LSD vaccine with an intervals 4and 12 week (G4\&G5); Our result agreed with Oliveira et al. (2000) who reported the best period for boostering was $4^{\text {th }}$ and $8^{\text {th }}$ weeks 
after initial vaccination and also agree with Claire (2008), then the $2^{\text {nd }}$ group $(\mathrm{G} 2)$ that was vaccinated with attenuated SP vaccine; then the other groups $(6 \& 7)$ which were successively vaccinated with inactivated LSD before attenuated SP with different intervals (4\&12 weeks), and group 8 that was simultaneously vaccinated with the attenuated SP vaccine and inactivated LSD vaccine at the same time while the animals vaccinated with the inactivated LSD vaccine recorded the least antibody response but still protective .

From the obtained result, it has been found that the antibody titre of the contact and isolated unvaccinated group (G9) persist negative all over the time of experiment (6ms) which meaning that the vaccines virus not transmitted from the vaccinated to the susceptible, which were in agreement with Aboul-Soud (1995); Amera (1997) and Olfat (2000).

Hosmani et al. (2004) reported that the estimation of the increased levels of antibody titre could be demonstrated by both indirect ELISA and SNT.

Finally the results in table (3) proved that the successive vaccination initially with attenuated SP vaccine induced immunological memory against Capripox (LSD) in bovines, and when boosted with inactivated LSD vaccine elevated the titres significantly and create relative acquired immunity subsequent to the homologous live attenuated LSD vaccine and overcome the other vaccines.

In contrast initial vaccination with inactivated LSD vaccine and boostered with attenuated SP vaccine produce slight rise of capripox antibody titre; our result affirm the results recorded by Oliveira et al., (2000) who found that "the live virus used as a second vaccination could be neutralized by already circulating antibodies produced in response to the primary vaccination", and also agreed with the US General recommendation on immunization (2011) recorded that the inactivated vaccines are generally not affected by circulating antibodies to the antigens while live attenuated vaccines may be affected by circulating antibodies to the antigens.

Attenuated sheep pox vaccine is the subsequent after the successive (attenuated SP then inactivated LSD) and previously the other successive vaccine, simultaneous vaccination and inactivated LSD vaccine.

Ben-Gera et al., (2015) concluded that "the Neethling vaccine is significantly more effective than protection conferred by X10 RM65 in preventing LSD morbidity".

Our results also agreed with Inaba et al. (1974) who found "that consecutive vaccination with live attenuated virus followed by inactivated virus resulted in a stronger and more durable neutralizing antibody response than vaccination with live attenuated 
vaccine alone or with two doses of the inactivated vaccine".

Inactivated LSD vaccine did not provide high serological results i.e. low antibody that meaning short term immunity which may referred to a number of factors, that including the changes of virion and the fact that immunity to capripox viruses is considered to be mainly cell mediated, which is better stimulated by the use of a live vaccine. Our result in agreement with Boultr et al. (1971) who reported "that even high level of antibody fulfilled through immunization using an inactivated preparation will at best give only short term protection as these vaccines are derived from intracellular virus released by freeze-thawing infected tissue culture".

There is an evidence that the cell mediated immune response play an important and main role against capripox beside humoral immunity (Ahmed et al., 2007).

Mild skin sensitivity reaction at site of vaccine injection is nearly appeared on the previously vaccinated animal and differed from group to the other and without clinical response; this is agree with previously described by Harumi, (2015) and Tizard (2004) who mentioned that the delayed hyper sensitivity is examined at site of injection 72-96 hours post injection and the positive reaction consisting of diffuse hard lump of variable sizes at the injection site. On the other hand the control unvaccinated animals after sensitization showed no any obvious hypersensitivity reactions at inoculation sites within three days post-inoculation but the rounded nodules at the site of inoculation were appeared with mild enlargement of the superficial lymph nodes within 2 weeks, without generalization and temperature developed up to 4040.6 C. Also the intradermal skin test was used to determine the immune status of cattle and sheep against SPV and LSDV (Capstic and Coackly, 1962; Hanan, 2000 and Soad et al., 2007).

On the other hand Gari et al. (2015) found that the Gorgan GTP vaccinated cattle showed stronger levels of cellular immune responses measured using Delayed-Type Hypersensitivity (DTH) reactions at the vaccination site indicating higher levels of immunogenicity produced by the GTPV vaccine in cattle, than Neethling and KSGP O180 vaccine vaccines.

In conclusion the present study showed that successive immunization with the attenuated sheep pox former to the inactivated LSD vaccine, in general stimulated high immune response nearly like that obtained from vaccination with the homological effect of attenuated LSD vaccine, but the attenuated LSD vaccine has a disadvantage from the probability of virus reversion and blood suckling arthropods (insect and tick) transmission. 
Field trial should be applied to provide optimal protection, duration and recommended immunization schedules should be flowed as closely as possible.

\section{References}

Aboul Soud, E. A. (1995): Studies on the adaptation of lumpy skin disease virus (LSDV) in cell cultures. Ph. D. Thesis, Microbiol. Faculty Vet. Med. Alexandria Univ. Agag, B.I.; Mousa, S.; Hassan, H.B.; Saber, M.S.; El-Deghidy, N.S. and Abdel Aziz, A.M. (1992): Clinical, Serological and biochemical studies on LSD. J. appl. Anim. Res.,1:13-2.

Ahmed, A.M.; Mukhtar, M.M.; El Hussein, A.m.; Tageldin, A.M. Nour and Fadol, M.A. (2007): Immune response of sheep vaccinated with Capripox vaccine. Vet. Res.; 1(1): 12-16.

Ali, A.A., Esmat, M., Attia, H., Selim, A., Abdelhamid, Y.M., (1990): Clinical and pathological studies on lumpy skin disease in Egypt. Vet. Rec. 127, 549-550.

Amal A. F. Abdel - Fattah (2003): the role of different adjuvants on the immune response of inactivated lumpy skin disease vaccine. Ph.D. thesis .Faculty of Vet. Med. Cairo University.

Amal, A. Fatouh, Amira, A. ElSaid, Soad M. Soliman and Michael, A. (2007): Immunological study on Lumpy skin diseas vaccines. Zag. Vet. J. Issn.11101458. Vol. 35, No.1 PP.14-19.
Amira, A. El-Said (1997): Evaluation of lumpy skin disease virus vaccine using cell-mediated immune parameters. M.V.Sc. thesis Virology, Fac. Vet. Med., Cairo Univ.

Ayelet, G., Abate, Y., Sisay, T., Nigussie, H., Gelaye, E., Jemberie, S., Asmare, K., 2013. Lumpy skin disease: preliminary vaccine efficacy assessment and overview on outbreak impact in dairy cattle at debre zeit, central Ethiopia. Antivir. Res. 98,261-265.

Babiuk, S.; Wallace, D.B.; Smith, S.J.; Bowden, T.R.; Dalman, B.; Parkyn, G.; Copps, J. and Boyle, D.B. (2009): Detection on antibodies against Capripox viruses using an inactivated sheep pox virus ELISA. Transbound. Emerg. Dis. 56:132-141.

Barnard B. J., Munz E., Dumbell K., and Prozesky L.(1994): Lumpy skin disease. in Infectious diseases of livestock, eds Coetzer J. A. W., Thomson G. R., Tustin R. C. ( Oxford University Press, Cape Town, South Africa), 1:604-612.

Ben-Gera J , Klement E , Khinich E , Stram Y , Shpigel NY (2015): Comparison of the efficacy of Neethling lumpy skin disease virus and x10RM65 sheep-pox live attenuated vaccines for the prevention of lumpy skin disease The results of a randomized controlled field study. Vaccine. 2015 Sep 11;33(38):4837-42.

Bhanuprakash, V.; Indrani, B.K.; Hosamani, M. and Singh, R.K. (2006): The current status of 
sheep pox disease. Comp. Immuno. Microbio. and Infect. Dis.; 29(1): 27-60.

Boulter, E.A.; Zwartouw, H.T.; Titmuss, D.H.J. and Maber, H.B. (1971): the nature of the immune state produced by inactivated vaccinia virus in rabbit. Am. J. Epidemiol. 94,612-620.

Brenner J, Bellaiche M, Gross E, Elad D, Oved Z, Haimovitz M, Wasserman A, Friedgut O, Stram Y, Bumbarov V, Yadin H, (2009): Appearance of skin lesions in cattle populations vaccinated against lumpy skin disease: statutory challenge. Vaccine, 27(10):15001503.

Capstic, P.B. and Coackley, W.(1962): Lumpy skin disease: the determination of the immune state ofcattle by an intradermal test. Res. Vet. Sci., 3(3):287-291.

Capstick P. B. (1959): Lumpy skin disease-experimental infection. Bull. Epizoot. Dis. Afr. 7:51-62.

Carn V. M. (1993) : Control of capripoxvirus infections. Vaccine 11:1275-1279.

Clair A. S. (2008): Vaccine Immunology, Section 1:Genneral aspects of vaccination.

Coetzer J. A. W., Thomson G. R., and Tustin R. C. (1994): Poxviridae. in Infectious diseases of livestock, eds Coetzer J. A. W., Thomson G. R., Tustin R. C. ( Oxford University Press, Cape Town, South Africa), 1:601-603.

Daoud, A.M.; Michael, A.; Soad, M. Soliman; Samir, S.S. and Aboul-Soud, E.A. (1998):
Production of lumpy skin vaccine in Egypt. $4^{\text {th }}$ Vet. Med. Zag. Congrress, 117-124.

Davies F. G. (1991): Lumpy skin disease of cattle: a growing problem in Africa and the near east. World Anim. Rev. 68, 37-42.

Davies F. G. (1982): Observations on the epidemiology of lumpy skin disease in Kenya. J. Hyg. 88:95102.

Davies F. G. (1991): Lumpy skin disease, an African capripox virus disease of cattle. Br. Vet. J. 147:489-503.

Davies, F.G., and Otema, C. (1981): Relationship of capripox viruses in Kenya with two Middle Eastern strains and some orthopox viruses. Res. Vet. Sci., 31(2):253255.

Eeva S.M. T, Caroline R., Katarzyna B-B, Nick J. K, Shadi A, Lorraine F, Mark R. H, Charles E. L and Peter P.C. M. (2014): Characterization of sheep pox virus vaccine for cattle against lumpy skin disease virus. Antiviral Research 109 (2014) 1-6.

El-Kholy AA, Soliman HMT, Abdelrahman KA, (2008): Polymerase chain reaction for rapid diagnosis of a recent lumpy skin disease virus incursion to Egypt. Arab Journal of Biotechnology, 11(2):293-302.

Fields B. N., Knipe D. M., Howley P. M., and Fenner F.(1996): Poxviruses. in Fields virology. (Lippincott-Raven, Philadelphia, Pa), pp 2673-2702. 
Flint, S. J.; Enquist, L.W.; Krug, R.M.; Racaniello, V.R. and SKalKa, A.M. (2000): Virology, Prevention and control of viral diseases. ASM, Press, Washington, D.C.

Gari G, Abie G, Gizaw D, Wubete $A$, Kidane $M$, Asgedom $\mathbf{H}$, Bayissa B, Ayelet G, Oura CA, Roger F, Tuppurainen ES (2015): Evaluation of the safety, immunogenicity and efficacy of three capripoxvirus vaccine strains against lumpy skin disease virus. Vaccine. 2015 Jun 22;33(28):325661. doi:

10.1016/j.vaccine.2015.01.035.

Hanan, A. F. (2000): Studies on intradermal allergic test of lumpy skin disease virus in cattl. Ph. D.thesis, Fac. Vet. Med., Cairo.

Harumi, J. MD. (2015): Delayed type Hypersensitivity. Med scapeDrug and disease.

House, J.A.; Terrance, M.; Wilson, T.M.; El-Nakashly, N.; Abdel Karim, I.; Ismail, I.; ElDanaf, N.; Mousa, M.A. and Ayoub, N.N. (1990): The isolation of lumpy skin disease virus and bovine herpes virus 4 from cattle in Egypt. J. Vet. Diag. Invest., 2: 111Hu SL., Klaniecki J., Dykers T., Sridhar P. and Travis BM. (1991): Neutralizing antibodies against HIV-1 BRU and SF2 isolates generated in mice immunized with recombinant vaccinia virus expressing HIV1(BRU) envelope glycoproteins and boosted with homologous gp160.
AIDS Res Hum Retroviruses.1991; 7:615-620. [PubMed: 1768463].

Inaba Y., Kurogi H., Takahash A., Sato K., Omori T., Goto Y., Hanaki T., Yamamoto M., Kishi S., Kodama K., Harada K. and Matumoto M. (1974): Vaccination of cattle against bovine ephemeral fever with live attenuated virus followed by killed virus. Arch Gesamte Virusforsch 44:121-132.

Kallesh, D.J.; Hosamani, M.; Balamurugan, V.; Bhanuprakash, V.; Yadav, V. and Singh, R.K. (2009): Quantitative PCR : A quality control assay for estimation of viable virus content in live attenuated goat pox vaccine. Ind. J. Exper. Biol.; 47: 911-915.

Khalafalla, A.I., Gaffar Elamin, M.A., Abbas, Z., (1993): Lumpy skin disease: observations on the recent outbreaks of the disease in the Sudan. Rev. Elev. Med. Vet. Pays Trop. 46, 548-550.

Kitching, R.P. (1986): Passive protection of sheep against capripox virus. Res. Vet. Sci., 41(2): 247250.

Kitching, R.P.; Hammond, J.M. and Black, D.N. and Taylor, W.P. (1986): A single vaccine for control of capripox infection in sheep and goat. Res. Vet. Sci., 42: 53-60.

\section{MacOwen R.D.S.}

(1959):

Observation on the epizootiology pf lumpy skin disease during the first year of its occurrence in Kenya. Bulletin of Epizootic Diseases of Africa 7,7-20.

Marshall, M., (2006): Available at: http://www.promedmail.org/pls/ape 
x/f?p=2400:1001:::NO::F2400_P10 01_BACK_PAGE,F2400_P1001_P UB_MAIL_ID:1000,33506 (accessed June10, 2006).

Martin, W.B.; Erhan, M. and Onar, B. (1975): Studies on sheep pox vaccine serum-virus neutralization test. Pendik Vet. Kont. ve Arastirm Institusu Dergisi, 8 (1): 26-47.

Mervat, I.I. (1999): Preliminary studies on inactivated lumpy skin disease virus vaccine. Ph.D.Thesis (virology), Fac. Vet. Med., Cairo. Univ.

OIE (1989): Lumpy skin disease. Manual of Recommended Diagnosis volume 1, A 1007:1-5.

OIE Manual Volume I (2004): Volume I Part I Section I.1. Sheep pox and goat pox. Chapter 2.1.10. P: $211-220$.

OIE Terrestrial Manual (2010): Chapter 2.7.14 Sheep pox and goat pox in manual of Diagnostic Tests and Vaccines for Terrestrial Animals. 1-12. and Chapter 2.4.1 4. Lumpy Skin Disease.

Olfat, E. Nackhla (2000): Study on goat pox virus vaccine, Ph.D. Thesis, (Virology), Faculty of Vet. Med., Cairo University, Egypt.

Oliveira, A. N.; Andrade, C.R.; Da-Silva, M.C.; Moura, W. C. and Contreiras, E.C. (2000): Immune response in cattle vaccinated against rabies, Mem. Inst. Oswaldo Cruz, Rio de Janeiro, 95 (1): 83-88.

Omnia H. R., Ausama A. Y., Amr A. E. and Adel A. F. (2014): Evidence of replicating Lumpy Skin
Disease virus in viscera of Ixodid ticks collected from naturally LSDV-Infected cattle: first record. $12^{\text {th }}$ scientific conference, Cairo Uni. Fac. of Vet. Med.

Omyma, M. El-Desawy (2008): Recent isolation and identification of lumpy skin disease virus from cattle in Egypt. Egypt J.Comp. Path and Clin. Path. 21,(1): 139-147.

Rao, M.V.S. and Malik, B.S. (1982): Behaviour of sheep pox, goat pox and contagious pustular dermatitis viruses in cell culture. Ind. J. Compara. Microbiol. Imm,. and Infe. Dis. 3(1): 26-33.

Reed, L.I. and Muench, H.A. (1938): A simple method for estimating fifty percent end point. Amer. J. Hyge.; 27: 493-497.

Rizkallah, S.S. (1994): Further studies on sheep pox disease in Egypt. Ph.D. Thesis, Vet. Med. College, Cairo University, Egypt.

Saber, M.S.; Daoud, A.M.; Fatehia, M. Mahamed; Hussein, H.A.; Michael, A. M.; Mervat, A. M.; Yousif, A.A. and Amin, A.S. (2000): Preparation of inactivated lumpy skin disease virus vaccine. Vet. Med.J. Giza, 40(4); 633-646.

Sadhukan, T.; Nag, N.C.; Ray, J.P.; Naundi, S. and Das, R. (1998): Application of ELISA in the diagnosis of goat pox outbreak.

Singh, M.P. and Rai, A. (1991): Adaptation and growth of sheep pox virus in Vero cell culture. Indian Veterinary Medical Journal. 15(4): 245-250.

Soad. M.S, Abd El-Razik. B.A, Amal. A.F, Taha. M.M and 
Micheal .A (2007):Trials for production of sheep and goat pox allergen,

Egypt.Vet.Med.Assoc.67 No 3:171179 (2007).

Somasundaram, M.K., (2011): An outbreak of lumpy skin disease in a holstein dairy herd in Oman: a clinical report. Asian J. Anim. Vet. Adv. 6, 851-859.

Tamam, S.M. (2006): Isolation of lumpy skin disease virus from naturally infected cattle previously vaccinated with live attenuated sheep pox virus vaccine. Bs. Vet. Med. J. 16(1), 27-31.

Tiwari, A.K. and Negi, B.S. (1995): Neutralization ability precipitinogens of goat. Ind. J. Compar. Microbiol. Immunal. and Infe. Dis, 16(1-2): 64-65.

Tizard, I. (2004): Vetrenary immunology $7^{\text {th }}$ edition, chap 29 P.375.

Tulman ER, Afonso CL, Lu Z, Zsak L, Kutish GF and Rock DL, (2001): Genome of lumpy skin disease virus. Journal of Virology, 75, 7122-7130.

Tulman ER, Afonso CL, Lu Z, Zsak L, Sur JH, Sandybaev NT, Kerembekova UZ, Zaitsev VL, Kutish GF and Rock DL, (2002): The genomes of sheeppox and goatpox viruses. Journal of Virology, 76, 6054-6061.

Tuppurainen E. S. M. (2004): The detection of LSD virus in samples of experimentally infected cattle using different diagnostic techniques. MVSC Vet. Tropical.
Fact. Vet. Sci. University of Pretoria.

Tuppurainen E. S. M. and Oura C. A. L. (2012): Review: Lumpy Skin Disease: An Emerging Threat to Europe, the Middle East and Asia. Transboundary and Emerging Diseases. doi:10.1111/j.18651682.2011.01242.x .Blackwell Verlag GmbH • 59 (2012) 40-48.

Tuppurainen E. S. M., Venter E. H., Shisler J. L., Gari G., Mekonnen G. A., Juleff N., Lyons N. A., Clercq,K. De, Upton C., Bowden T. R., Babiuk S. and Babiuk L. A. (2015): Review: Capripoxvirus Diseases: Current Status and Opportunities for Control. (c) 2015 The Authors. Transboundary and Emerging Diseases Published by Blackwell Verlag GmbH

Uppal, P.K.; Nilakanton, P.R. and Sakhubai, P.R. (1967): Observation on the use of live and inactivated virus vaccines against sheep pox. Ind. Vet. J. 44:815-827.

US General recommendation on immunization (2006): Interval spacing of vaccines. Vol.1(55) No.RR-15.

USEPA, Manual of Methods for Virology (1984): United State Environment Protection Agency Manual of Method for virology.

Vegad, J.L. and Sharma, G.L. (1973): Cutaneous and pulmonary lesions of sheep pox. Indian J. Anim. Sci., 43(12): 1061-1067.

Williams, R. (1987): ELISA technique for diagnosis of African 
horse sickness virus. J. of Vet. Diag. Invest., 11(2): 9-11.

Yeruham I, Nir O, Braverman Y, Davidson $M$, Grinstein $\mathbf{H}$, Haymovitch $M$ and Zamir $O$, (1995): Spread of lumpy skin disease in Israeli dairy herds. Veterinary Record, 137, 91-93.
Yeruham I, Perl S, Nyska A, Abraham A, Davidson $\mathbf{M}$, Haymovitch M, Zamir $O$ and Grinstein H, (1994): Adverse reactions in cattle to a capripox vaccine. Veterinary Record, 135, 330-332.

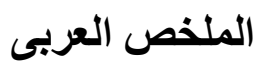

تأثير التحصين التبادلى بلقاحى جدرى الاغنام المستضعف و الجلد العقدى المثبط ضد

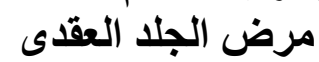

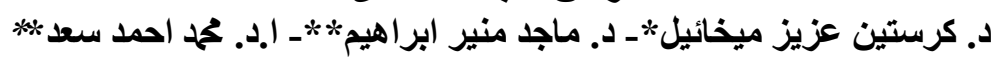

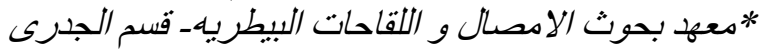

$$
\begin{aligned}
& \text { **/المعل الدركزى للرقابه على المستحضرات الحيويه البيطريه }
\end{aligned}
$$

مستويات مختلفه من الحمايه من فيروسات مجموعه الكابري الجدريه نبحث عن استخدام لقاحات

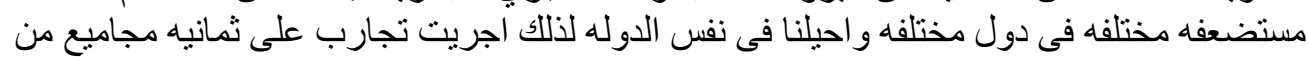

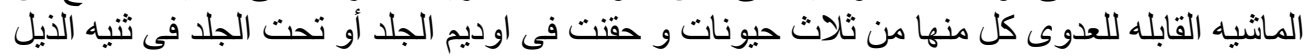

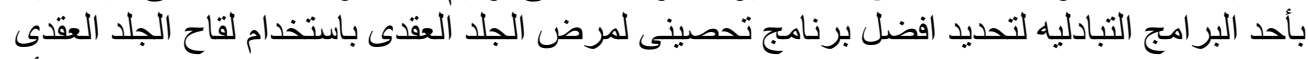

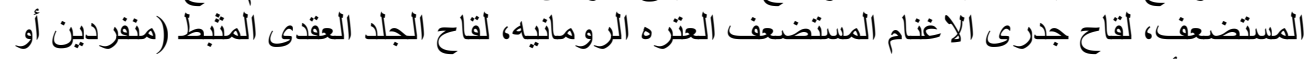

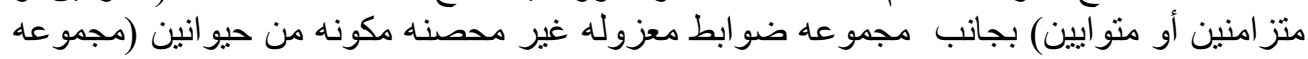

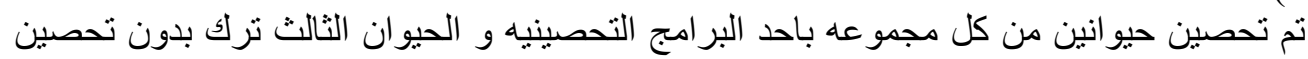

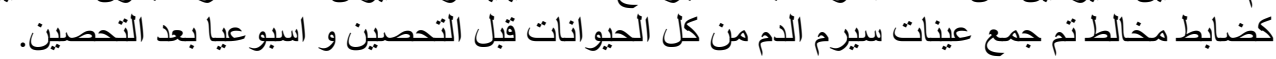

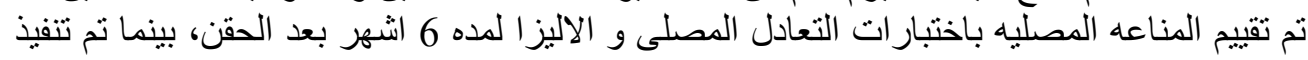

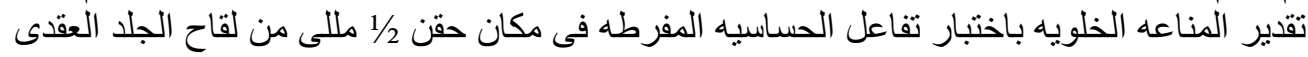

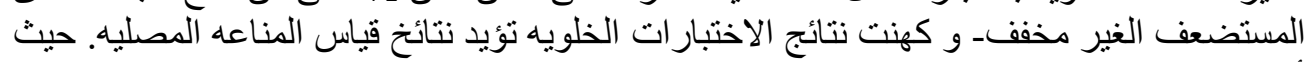

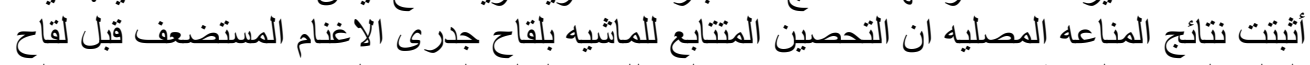

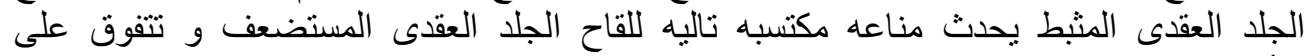

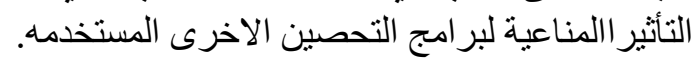

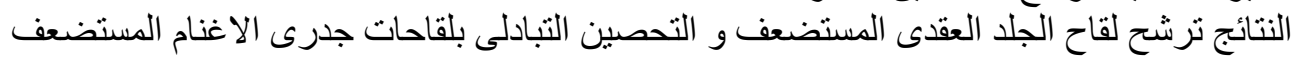

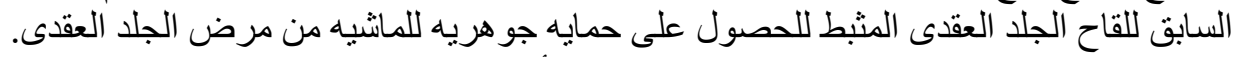

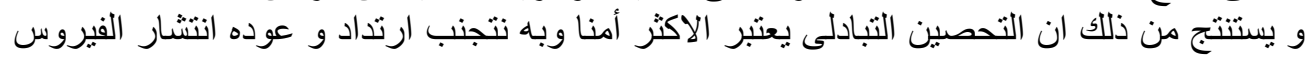
بالحشر ات النى تتخذى على الأدماء. 